\title{
THE CHARTIST CRISIS IN BIRMINGHAM
}

On the spectrum of Victorian politics Birmingham stands at one extreme - the exemplar of class harmony and co-operation. Where other towns were torn by strife and discord, here the forces of cohesion and stability were triumphant. An alliance between the middle and working classes remained the cardinal fact of political life from Thomas Attwood's Political Union to Joseph Chamberlain's caucus. Political tranquillity reflected the deeper harmony of a well integrated culture, in which the masters and artisans of a small workshop economy shared a commitment to the social and moral values of the community. 1

The one exception to the prevailing political pattern occurred in I 839 , when the Chartist crisis erupted menacingly from the ruins of a shattered alliance between the classes. For three years Birmingham experienced the sullen politics of class conflict.

The Chartist episode underlines the critical importance of middleclass decision and initiative in shaping the political evolution of the town. Birmingham had not received a providential exemption from the tensions that troubled early Victorian England. Although the social and cultural configuration of the town was highly conducive to an accommodation between the classes, it did not remove the omnipresent possibility of class conflict inherent in every early Victorian industrial city. To take full advantage of Birmingham's favorable situation required the firm resolve and adventurous idealism of a middle-class elite. When the middle-class Radicals suffered a 1 For the social and economic basis of Birmingham politics see Asa Briggs, Thomas Attwood and the Economic Background of the Birmingham Political Union, in: Cambridge Historical Journal, IX, No. 2, (1948), and The Background of the Parliamentary Reform Movement in Three English Cities, ibid., X, No. 3, (1952). See also my article, The Artisan and the Culture of Early Victorian Birmingham, in: University of Birmingham Historical Journal, IV, No. 2, (1954). 
momentary failure of nerve in 1839 , the political structure that appeared to have been erected on such solid foundations collapsed completely. Only the reassertion of middle-class leadership in I 842 resolved the Chartist crisis and enabled the cohesive tendencies of the culture to operate effectively once again.

\section{I}

The Chartist crisis in Birmingham was rooted in the universal predicament that confronted the industrial towns of early Victorian England. While workingmen were bound to demand the vote as a matter of right, the bourgeoisie could not but refuse to entrust its affairs to the hazard of the democratic process. The inevitable refusal was certain to intensify distrust and antagonism between the classes. Denied the most elementary political justice, the workingmen would necessarily become more threatening. Faced with a seeming confirmation of their worst fears about the character of a mass electorate, the middle classes could only stiffen their resistance. There was no easy way out of the vicious circle. For some time, however, Birmingham appeared to have found a means of escape.

Between 1830 and 1838 the astonishingly democratic character of middle-class Radicalism in Birmingham dispelled every hint of conflict between the classes. During the campaign for the first Reform Bill the Birmingham Political Union proudly enrolled "the lower and middle classes of the people" and launched an unprecedented mass agitation for parliamentary reform. Although the Union stopped far short of advocating universal manhood suffrage, its assertion of the principle that all classes ought to be adequately represented in the House of Commons was enough to win fervent working-class support. In 1837 a resurgent middle-class Radicalism vastly enhanced its popular appeal by reviving the Political Union in a demand for nothing less than universal manhood suffrage. With this objective in mind Radical merchants and manufacturers found themselves carried away by the prospect of a mass movement that would produce "such an excitement out of doors as would compel their rulers to listen." 1 Thomas Attwood and the leaders of the Political Union became obsessed with the vision of a gathering of "the masses" that would wrest universal suffrage from the government by the moral force of public opinion. Under these circumstances, of course, there was not a trace of conflict between the classes. When the Birmingham Radicals entered the national political arena, however, they set in motion a train of events that eventually overturned the established pattern of local politics.

1 Birmingham Journal, 17 March 1838. Cited hereafter as B.J. 
Early in 1838 the Political Union advanced the startling proposal for a National Convention, to be composed of delegates to be elected by the people. ${ }^{1}$ The Convention was to supervise a great campaign for universal manhood suffrage. The climax of the agitation was to be the presentation of a National Petition to Parliament. In setting out to organize such a movement Birmingham's middle-class Radicals played an important part in the genesis of Chartism. The culmination of their efforts came with the great meeting of August 6,1838 , which has been described as "the official beginning of the Chartist Movement." 2 Representatives of working-class groups from various parts of the country attended the meeting at Holloway Head ${ }^{3}$ and agreed to unite their efforts on behalf of the National Petition and the People's Charter. They decided to arrange for the election of delegates to a National Convention, which was to be held in London early in the following year. The Birmingham delegation, elected by the Holloway Head meeting, looked forward expectantly to a repetition of local triumphs on a national scale in 1839 . These expectations were shortlived.

In the months following the meeting of August 6, Birmingham's middle-class Radicals came into disquieting contact with unfamiliar social and political forces, personified by Feargus O'Connor. They found it difficult to maintain their uncommonly democratic orientation in the face of the evident popularity of O'Connor's physical force ideas. Early in 1839 their sudden disenchantment with the movement they had sponsored alienated the Birmingham workingmen and precipitated the Chartist crisis. When the middle-class Radicals abruptly ceased their agitation for universal suffrage not even Birmingham could escape the ordinary tribulations of early Victorian politics.

Until the autumn of 1838 the middle-class Radicals had assumed that "the masses" would follow their lead and no other. Feargus O'Connor rudely upset that assumption, not only in England but in Birmingham itself. After a brief but successful appearance at the Holloway Head meeting in August, O'Connor won considerable local support for his physical force ideas. In September in the Town Hall he advised the crowd to "try their right arms" to get their rights. His words evoked "rapturous applause", which continued for some time. ${ }^{4}$ Returning to the North of England, O'Connor proclaimed his doctrines even more

1 Ibid., 3 February 1838.

2 Mark Hovell, The Chartist Movement (Manchester, 1918), p. 107.

3 Hovell erroneously states that the meeting took place at Newhall Hill. See B.J., I I August 1838 .

4 Ibid., 8 september 1838 . 
violently. Disturbed by reports of O'Connor's speeches and aware of his local popularity, the leaders of the Political Union at the end of October began a campaign to convince the rank and file of the unsoundness of physical force Chartism. Although the Council of the Union ran into some opposition, it seemed to have succeeded fairly well at first. ${ }^{1}$ When O'Connor himself presented his case in Birmingham, however, it became clear where popular sympathies lay. At a meeting of the Union in November he argued that a deadline should be set for parliamentary acceptance of the Charter; if the deadline passed without favorable action, then physical force would be used. Although John Collins, the only Birmingham workingman who was a delegate to the Convention, spoke against the proposal, the crowd obviously agreed with O'Connor. Content with this informal expression of support, O'Connor announced that he was willing to leave the question of timing to the Convention. ${ }^{2}$ The following week he received another enthusiastic ovation from a Birmingham crowd. ${ }^{3}$

The middle-class Radicals now made a final attempt to deal with the O'Connor problem. They persuaded him to approve in advance a resolution condemning physical force. At the special public meeting convened to consider the resolution, $\mathrm{O}^{\prime}$ Connor gave it his blessing, but his speech indicated that he had not really changed his mind. He was willing to pay lip service to a condemnation of physical force doctrines, because he wanted to ensure the attendance of the Birmingham delegation at the Convention, where he expected to have his way. The meeting passed the resolution, but the crowd reserved its loudest cheers for the more inflammatory passages in O'Connor's speech.4 By this time the middle-class Radicals had lost most of their enthusiasm for the project they had launched so hopefully a few months before. When Thomas Attwood and his lieutenants found that physical force ideas had won such strong support both in Birmingham and in the country at large, they began a hasty withdrawal from Chartist politics.

As the middle-class Radicals showed signs of flagging interest, an independent working-class movement came into being, under the leadership of moderate artisans like Henry Watson and Thomas Baker, who remained in control for a few weeks. The immediate issue that gave rise to this first split within the ranks of Birmingham Chartism concerned the collection of the National Rent, which was to finance the projected agitation. At the meeting of the Council of the

1 Ibid., 3 November, Io November 1838 .

2 Ibid., 17 November 1838 .

3 Ibid., 24 November 1838 .

- Ibid., r December 1838 . 
Political Union on November 13, Watson and Baker proposed that a system of district meetings be set up in order to raise money more efficiently. When the Council rejected the proposal, Watson voiced the resentment that had been building up against the middle-class Radicals even among the most cautious and conservative of the workingmen: "If the propelling wheel to the resolution had been some wealthy man, there would not have been any objection raised to it. There was rather a tendency to aristocratic feeling amongst them, and when a wealthy man moved, they generally carried those resolutions." 1 The artisans now decided to collect the National Rent themselves and in December they began to meet regularly every Thursday for this purpose. ${ }^{2}$ John Collins and Henry Watson took the initiative in setting up a Managing Committee for the Collection of the National Rent. Although Collins served as chairman of the group, the election of Edward Brown as secretary portended a decisive change in working-class politics in Birmingham.

The moderates were soon pushed aside by men like Brown, the impassioned disciples of O'Connor who were ready to preach class war to cheering crowds. Of the old guard of working-class leaders only Collins remained active, in a vain attempt to prevent the complete triumph of the extremists. When Henry Watson took the chair at the first of the Thursday meetings, he found that the proceedings were dominated by two O'Connorites; and shortly thereafter he withdrew from political activity. At this first meeting Brown defended Joseph Rayner Stephens, and quoted with approval Stephen's remarks on the usefulness of "an ounce of lead and the cold steel." 3 The meeting approved a resolution introduced by John Fussell, expressing confidence in O'Connor. Birmingham was soon to have its first and last experience with the politics of class struggle.

In the meantime the leaders of the Political Union made no attempt to stem the O'Connorite tide. In fact, by expressing doubts about the value of the Convention, they encouraged the workingmen to turn to the extremists. When Attwood finally attended a meeting of the Council of the Union on January is, he said that he was fearful that "imprudent and dangerous men" would gain control of the Convention and destroy its efficiency. His audience could take but small comfort from his assurance that in the event of a "failure of discretion, virtue,

1 Ibid., 17 November 1838 .

2 Ibid., 15 December 1838 .

3 Ibid., 22 December I 838 ; British Museum, Add. MSS 27,820 (Francis Place Collection), p. 352 . 
or efficiency" in the Convention, "the Birmingham Union would still remain an unflinching and efficient rallying point for the country." 1

For their part, the O'Connorite artisans in Birmingham gave Attwood little cause to expect "discretion" from the Convention. Speaking after the regular meeting of the Council of the Political Union on January 15, Edward Brown conceded that his group used strong language and explained that "they were goaded to it by the oppression of their rulers." Although they would try moral means first, they would go on to something else if necessary. ${ }^{2}$ Two weeks later the O'Connorites displayed their growing hostility to the middle classes when the Town Council called a public meeting to petition Parliament for the repeal of the Corn Laws. John Donaldson denounced the proposal as a diversion from the Charter and chided the Councillors for thus betraying "the interests of the workingmen, on whose shoulders they were carried to the eminence they now enjoy." The crowd at the public meeting evidently felt much the same way on the matter. Speakers favoring the anti-Corn Law petition were noisily interrupted. There were repeated shouts of "Universal Suffrage", "No Surrender", "No Whig Trickery", "Our Rights and Nothing Less". A number of women shook tin boxes and called for contributions to the National Rent. An amendment rejecting the petition was passed with only thirty dissenting votes. ${ }^{3}$ Although most of the middle-class Radicals of the Political Union supported the rejection, because they still wanted primary emphasis put on the suffrage issue, the temper of the crowd did little to reassure them about the willingness of "the masses" to follow their old leaders.

At the meetings of the Council of the Political Union in February and March there were frequent clashes between the middle-class Radicals and the working-class supporters of O'Connor. At one such meeting a deputation from "the workingmen's committee", including Brown and Donaldson, presented an address to the Birmingham delegation to the Convention. The deputation urged the delegates - none of whom was present at the meeting - that a year's adjournment of the Convention would be "fatal to the interests of the working classes." 4 In the next few weeks the workingmen became more and more critical of the absence of the leading Radicals from the meetings of the Council of the Union. ${ }^{5} \mathrm{~A}$ few middle-class Radicals did put in an appearance in March, but only in a last futile attempt to break up the National

1 B. J., I9 January I839.

2 Ibid.

3 Ibid., 2 February 1839.

4 Ibid., 23 February 1839.

5 Ibid., 9 March 1839. 
Rent Committee, which was now completely under the control of the O'Connorites. The Council voted unanimously to dissolve the National Rent Committee and demanded an accounting of its funds. ${ }^{1}$ The publication of the accounts at the next meeting brought a large attendance of middle-class Radicals. They came into conflict with a deputation headed by John Fussell and John Powell, who berated the Birmingham delegates to the Convention for failure to discharge their duties. ${ }^{2} \mathrm{~A}$ few days later matters came to a head when the Birmingham delegation, with the exception of John Collins, resigned from the Convention in opposition to the physical force doctrines that seemed to have won over the majority of the delegates. ${ }^{3}$ When the Council of the Union held its last meeting on April 9, the crowd greeted with scornful laughter a letter from Thomas Attwood stressing the importance of order and legality. ${ }^{4}$ The middle-class Radicals had bowed out of the picture, enabling the O'Connorites to take over the political leadership of the Birmingham working class.

The new leaders lost no time. Immediately after the resignation of the Birmingham delegation John Donaldson wrote to the Convention asking it to send a deputation of inquiry. When the request was granted, the O'Connorites, led by Brown and Fussell, held a preliminary meeting at Holloway Head to make preparations to receive the deputation. The meeting set up a Birmingham Observational Committee to look after the interests of the local workingmen now that the town's delegation to the Convention had resigned. The Committee included Fussell, Brown, Powell, Donaldson, and Henry Wilkes. Their speeches on this occasion set the tone for the ensuing agitation. Their theme was the betrayal of the working class by the middle class. They urged the working class to take matters into its own hands if necessary. Powell denounced the leaders of the Political Union for "using" the people to win the charter of incorporation only to "desert the artisans of Birmingham after they themselves had been put in possession of a nest." Fussell defended the right of the people to resort to physical force if other measures failed. According to Henry Wilkes the real traitors were not the physical force men, but those who had betrayed Chartist principles. Brown called on the meeting to rally round the Convention and forsake the Political Union, which had merely used the people as "tools" for its own purposes."

1 Ibid., I6 March 1839.

2 Ibid., 23 March 1839.

3 Ibid., 30 March 1839 .

4 Ibid., I 3 April 1839.

I Ibid., 30 March, 6 April 1839. 
The O'Connorites did not have a counter-ideology to proclaim in opposition to the doctrines of the Political Union. They simply preached the old Radicalism with a new proletarian and anti-middle class orientation. This was enough to provide the ideological basis for the tumultuous Chartist agitation that upset traditional political patterns in Birmingham in the spring and summer of 1839 . The chief factor motivating the movement was not O'Connorite ideas, but a sense of betrayal common to all segments of the local working class. The O'Connorites exploited that sentiment. They succeeded momentarily because the middle-class Radicals had surrendered without a fight.

Feargus O'Connor himself was the main speaker at the Holloway Head meeting that the Observational Committee had arranged to receive him and other members of the deputation from the Convention. He assailed the middle class and defended the right of the working class to bear arms. The crowd was all for him and at first refused even to listen when John Collins tried to defend the behavior of the Birmingham Radicals. After listening to Collins tather grudgingly, the crowd passed the resolution that he had opposed: "The working classes of Birmingham, in public meeting assembled, do hereby censure the conduct of... our late representatives to the General Convention." 1 A few years before they would have spoken, not in the name of the "working classes", but in the name of the "industrious classes", the category that the Radicals had used so well to gloss over class differences. On April 22, a meeting at Holloway Head elected three O'Connorites - Brown, Powell, and Donaldson - as the new delegation to the Convention. In an appropriate ceremonial conclusion there took place a burning of the "Birmingham Journal" and of a placard bearing the name of T. C. Salt. ${ }^{2}$ The last link with the middleclass Radicals had been broken and the situation soon got out of hand.

\section{II}

The O'Connorites proceeded to organize a series of meetings in the Bull Ring, a square in the center of Birmingham. The workingmen had become accustomed to meeting there early in 1839 , often after the weekly sessions of the Council of the Political Union, which were held indoors. By April the physical force group was reported to have acquired" a kind of independent existence by holding nightly meetings in the Bull Ring". In time the speeches became more inflammatory

1 Ibid., 6 April 1839 .

2 Ibid., 27 April 1839.

${ }^{3}$ Borough of Birmingham, Report of the Committee Appointed by the TownCouncil... to Investigate the Causes of the Late Riots (Birmingham, I840), p. 4. Cited hereafter as Report on Riots. 
and the crowds - numbered in the thousands - more rowdy. The more violent the speakers' language the more enthusiastic was the response. A letter from one of the O'Connorites, probably Fussell, described the situation early in May: "We had such a meeting last night as was never seen in this town before. There has been no work done here for this last week - all is excitement - the Bull Ring is crowded from morn till night, all anxious to hear the fate of the petition. The state of the fermentation is such that I have been obliged to address the people in the middle of the day for the purpose of protecting the peace." 1 The excitement increased when the Convention announced that it would meet in Birmingham on May 13. The crowds in the Bull Ring began to obstruct traffic, and the shopkeepers prevailed on the magistrates to issue an order prohibiting such meetings anywhere in the town. Thus began the long conflict between the O'Connorites and the municipal authorities which culminated in the July riots.

When Fussell consulted the magistrates about the prohibition, they explained that they had no desire to prohibit all public meetings. $\mathrm{He}$ agreed to find a better meeting place than the Bull Ring. On May ro the magistrates issued a more limited order, prohibiting public meetings in the Bull Ring. Fussell changed the meeting place to Holloway Head, an open area on the outskirts of the town, where a large crowd welcomed the Convention to Birmingham on May I3. Fussell's welcoming speech showed clearly that the change in venue did not mean a decline in militancy. He noted that "they had congregated in their immense masses, to give a glorious reception to the delegates who were endeavouring to work out their salvation." They were determined to get universal suffrage, "no matter what the middle classes might say." As for the meetings in the Bull Ring, he would even speak there if the Convention so ordered, in spite of the "scoundrels" who were trying to prevent him. If they dared arrest him, Birmingham would be a "hell upon earth". ${ }^{2}$ At this point the magistrates decided to intervene. A few days before they had sworn in 2300 special constables and strengthened the military force in the town with two companies of riflemen. They arrested Fussell and charged him with having used violent language at the Holloway Head meetings. The arrest had the desired effect. Fussell was released on bail, and his political acivity virtually ceased; at the summer assizes the charges against him were dropped. Edward Brown also was arrested and charged with having used violent language at the Bull

1 B.J., II May I 839.

2 Report on Riots, pp. 5-8; B.J., I 8 May I 839. 
Ring in March. He spent a few weeks in jail before he managed to raise money for bail. ${ }^{1}$

The removal of Fussell and Brown from the political scene did not lessen popular excitement. Large crowds attended the hearings before the magistrates on May 17 and cheered Feargus O'Connor's defense of the two men..$^{2}$ Although the Convention decided to adjourn before reconvening in Birmingham on July $\mathbf{I}$, the town remained in a state of tension and unrest. The Chartists took to invading public meetings. They noisily interrupted the first general meeting of the Birmingham Town Mission, in order to defend "the people's cause". Even the Reverend Timothy East, well known for his sympathy with the working classes, was received "with much disapprobation". ${ }^{3}$

In the meantime the Bull Ring meetings were resumed and became "more alarming and tumultuous" than before. Flags appeared for the first time. Instead of quietly going home after the meetings, the crowds formed noisy processions. On the other hand, the speakers in the Bull Ring, with the example of Brown and Fussell in mind, avoided violent language and merely read aloud from newspapers. Throughout June the magistrates tried to break up the meetings, but the most serious charge they could bring was the obstruction of traffic. Henry Wilkes was fined five shillings on June i 2 for obstructing traffic on High Street by "assembling a large concourse of persons" and reading to them from a newspaper. The "large concourse" consisted of only two or three hundred persons. ${ }^{4}$ Five days later he was fined forty shillings for the same offense before a slightly larger crowd. Prosecutions of this sort increased resentment against the magistrates, some of whom had been street corner orators themselves a few years before. In the course of his defense Henry Wilkes reminded one of the magistrates, P. H. Muntz, of his own Radical days: "It appears to me very strange that the working classes should now be prosecuted. In the year I832, when I took an active part, there were no such interruptions nor prosecutions. The influential gentlemen then took part with the people, and there were no such objections raised." 5

When the magistrates brought charges against other workingmen for obstructing traffic at Bull Ring meetings, the crowds at the hearings jeered at what appeared to be more examples of middle-class hypocrisy. When the magistrates lectured them, there was loud laughter. Edward

I B.J., I 8 May, 22 June, 27 July, Io August, I839; Northern Star, I 8 May, 25 May 1839; Report on Riots, pp. 9-13.

2 B.J., I 8 May I 839 .

3 J. A. Langford, A Century of Birmingham Life, (Birmingham, i871), II, pp. 58 I-2.

4 Report on Riots, p. I4; B. J., Is June 1839.

5 B.J., 22 June I839. 
Brown, free on bail, spoke on behalf of the defendants and summed up the sense of embittered disappointment that animated the Bull Ring meetings. The responsibility for the meetings, he argued, lay with "the gentlemen who drew us into it and then left us. The poor workingmen ought not to have all the punishment." From the point of view of justice, Brown was right. But the first responsibility of public officials is the maintenance of order, and the magistrates were understandably alarmed at the proceedings in the Bull Ring, especially since the O'Connorite agitators seemed to be part of a nation-wide conspiracy to win universal suffrage through physical force if necessary. Inevitably, then, the magistrates passed sentence, and the working class crowd in the Public Office lost all respect for the judicial process. The proceedings closed with a strange demonstration: "Three tremendous cheers were then given for the Convention, and three for the Charter; after which the room was cleared. It was altogether one of the most extraordinary scenes ever witnessed in a court of justice." 1

In this atmosphere the return of the Convention to Birmingham on the following Monday, July I, was bound to heighten the tension. On Monday, Tuesday, and Wednesday large crowds gathered in the Bull Ring and afterward marched through the streets. Since the piecemeal prosecutions in June had failed to end the meetings, there was heavy pressure on the Mayor, William Scholefield, to take more drastic action. Scholefield had proposed to conciliate the Chartists by permitting them to meet once a week in the Town Hall. Such a policy might have succeeded in quieting the agitation. But the Street Commissioners, who still controlled the use of the Town Hall, accepted Scholefield's proposal only in such restricted form that the workingmen were unable to take advantage of it in practice. ${ }^{2}$ The Mayor then had no choice but to try to cow the Chartists into submission by a show of force. Lacking a local police force, Scholefield requested the Home Secretary to send reinforcements from the London police. His request was granted and he went to London to fetch sixty policemen. They arrived in Birmingham at 8:00 P.M. on Thrusday, July 4 . Although Scholefield had instructed the police to avoid provocation, they paid no attention. Their provocative behavior was directly responsible for the riot that occurred shortly after their arrival. ${ }^{3}$

A little before 8:00 P.M. the Chartists had begun one of the most orderly of their meetings in the Bull Ring. Fussell, in his first public

1 Ibid., 29 June 1839.

2 Ibid., 29 June, 6 July 1839; Report on Riots, pp. 15-16.

3 Report on Riots, pp. 18-21; B. J., 6 July 1839. 
appearance since his arrest, was concerned mainly with avoiding the obstruction of traffic. The first speaker took a quiet line. The next speaker read quotations from a Tory newspaper. When the police arrived on the scene, he was almost finished and a procession was about to be formed. At this point the Mayor and a magistrate ordered the crowd to disperse and directed the police to arrest the speaker. The crowd "for a moment remained stationary, as though spellbound." Then the police advanced, cracking heads as they went, despite the fact that the crowd offered no resistance. The crowd took flight, with the police in pursuit. The infuriated workingmen now tore down shop shutters and armed themselves with whatever missiles they could find. The policemen, scattered into smaller groups, were unable to defend themselves. They were "surrounded and most of them overpowered - some were knocked down, some kicked, some stabbed and stoned." They were saved only by the timely arrival of soldiers. After further disorder the crowd moved on to Holloway Head. They proceeded back to town after arming themselves with railings at St. Thomas Church. When the troops approached, however, they threw down their weapons and scattered. Early the next morning a large group of Chartists met again at Holloway Head and eventually dispersed after the dragoons were called out. Throughout the day riflemen patrolled the streets. That night there was "a good deal of mobbing" in the town. Even the soldiers had trouble breaking up a "formidable rally" at Holloway Head. Saturday night there was more rioting in the Bull Ring; police and cavalry broke up the crowd. After a quiet Sunday, there was more trouble on Monday. The Bull Ring and the main streets were densely crowded. In clearing the streets the policemen "used very little discrimination. Several most orderly and inoffensive inhabitants fell beneath their staffs, with severely bruised heads and bodies." The rest of the week was calm. ${ }^{1}$

The local authorities were in no mood for conciliation. With ironic injustice, the magistrates arrested two of the more moderate Chartists, William Lovett and John Collins, for their part in drawing up a declaration by the Convention criticizing the police for their actions on July 4. In August they were sentenced to a year's imprisonment. ${ }^{2}$ This was enough to discourage any further mass agitation.

1 Report on Riots, pp. I9-25; B.J., 6 July, 13 July I 839.

2 B.J., I 3 July, ro August 1839 . The Birmingham magistrates werc being prodded by Lord John Russell to take strong action against the Chartist leaders. A. R. Schoyen, The Chartist Challenge (London, I958), p. 77, citing H.O. (Home Office Papers) 40/50, Russell to Scholefield. A more destructive disturbance took place in the Bull Ring on 15 July. But that was the work of a mob of boys who had no connection with the Chartist leaders. The boys took advantage of the excitment created by a Chartist procession to the 
For over a year after the Bull Ring riots, Chartist activity in Birmingham was dominated by the O'Connorites, who were not challenged until the moderates formed the Christian Chartist movement.

Despite the repressive measures of July, O'Connor's followers continued to meet and even succeeded in winning a certain amount of popular support. In September they were holding weekly meetings in an attempt to raise money for Lovett and Collins. Next they turned to the trade clubs with some success, arranging meetings of the carpenters and joiners, brass founders, shoemakers, tailors, and tin-plate workers. ${ }^{1}$ In December they elected Edward Brown as delegate to the Convention, which was preparing to meet again in London. ${ }^{2}$ But the O'Connorites were plagued by disunity and mutual suspicion, which prevented them from capitalizing on their momentary popularity as critics of the middle classes. James Porter, the shoemaker who acted as treasurer for the group, refused to pay Brown his expense money. Continual bickering of this sort delighted the chief of police: "These intestine quarrels can have but one effect, the breaking up of these meetings." He agreed with the Mayor that the best policy was to let the meetings "die a natural death, which it is evident they are doing." 3

Police spies added to the O'Connorites' troubles. Early in I 840 they were thrown into confusion by a dismal affair involving a former police spy, whose self-appointed role as agent provocateur had already led to his repudiation by his employers. The confessed spy, a man named Tongue, accused Brown and Fussell of having been in the pay of the police when they were organizing the Bull Ring meetings the year before. Although the accused denied the charge, the Chartists called a special meeting to consider Tongue's accusations. His failure to appear did not dispel the atmosphere of suspicion and distrust. Henry Wilkes denounced Brown as a spy, chiefly because the latter had not paid for his board and brandy while in prison in July. After Brown explained the circumstances, the meeting exonerated him. But Fussell continued to be distrusted and was not even permitted to

Warwick Road for the purpose of meeting Lovett and Collins, who had been released on bail. The rioters made their way to the Bull Ring, where they burned two houses and looted several shops. To a certain extent the rioters were protesting against further instances of police brutality during the previous week. See Report on Riots, Pp. 25-4I, and B. J., 20 July 1839.

1 B.J., I4 September 1839; William Lovett, Scrapbook (Birmingham Reference Library), II, pp. 109-10.

2 B. J., 4 January, II January 1840.

3 Home Office Papers, 4\%/56, letter from Francis Burgess, I January I840. (The letter carries the date „, 1839 "). 
speak in defense of Brown. ${ }^{1}$ The chief of police, in summing up the week's meetings, was able to write confidently to the Home Office: "The one last night was very large and noisy, but they were engaged principally in these meetings in attacks on each other, and on the subject of spies." 2 By September another police agent was reporting even greater disunity. ${ }^{3}$

Undaunted by their difficulties, the O'Connorites formed a branch of the National Charter Association and met regularly at a coffee house. ${ }^{4}$ The branch had only twenty-six members, but did its best to make up in militancy for lack of numbers. In March of 1841 the O'Connorites acquired a new leader, when George White, a "Northern Star" reporter, arrived in Birmingham. ${ }^{5}$

The chief advantage enjoyed by the O'Connorites was the widespread working-class resentment at the behavior of the middle classes. Early in 1840 , for example, O'Connorites and moderates alike rejected a well-intentioned scheme to organize a movement to demand adult suffrage based on literacy. Their main objection to the proposal was its middle-class sponsorship. J. H. Shearman, the local editor who originated the plan, was rebuffed when he held a meeting to determine working-class opinion on the subject. T. P. Green condemned the whole scheme as "altogether a middle-class proposition, and, as such, not deserving of the confidence of the working class." William Empson, a shoemaker who was to become one of the more cautious Chartist leaders of the 1840 's, also denounced the middle classes: "The workingmen had been deceived by them over and over again, and they must never trust them." Porter condemned Shearman's proposal as "a mere milk and water concern", and advised the working classes to play on the fears of the middle classes. The artisans were in no mood to take Shearman's advice: "Prayer to Him will do more for you than cursing your fellow-creatures. Temperance and abstinence will do more for you than arms and ammunition; and the charms of persuasion effect more than all the terrors of force. The man who is right is never afraid. Become right, and you will have all the attributes of God, the elements of nature, and the friends of humanity with you."'6 Two years later the Birmingham workingmen were ready to heed a similar plea from Joseph Sturge, but in 1840 they wanted to have nothing to do with middle-class leadership. The Chartist leaders

1 B.J., II January 1840 ; H.O., 40/56, letter from Burgess, II January 1840.

2 H.O., 40/56, letter from Burgess, 9 January 1840.

3 Ibid., report from Barnett to Burgess, 23 September 1840.

- Northern Star, 2r November, 5 December 1840.

5 B.J., I3 March 1841.

6 Ibid., 29 February, 7 March 1840. 
attended meetings held to advocate repeal of the Corn Laws only to insist on the priority of universal manhood suffrage. At one such meeting Edward Brown denounced the middle class for its failure to look after working-class needs and for its operation of the new Poor Law. ${ }^{1}$

The sentence passed on Brown when he came up for trial in April of I 840 was hardly calculatcd to disabuse the Chartists of their belief in the untrustworthiness of their social superiors. Charged with having engaged in seditious activity in the Bull Ring the previous June, he was found guilty and sentenced to eighteen months in the county jail. Brown made the mistake of speaking his mind at the trial. In what was described as a "Iong and able address" he denounced the hypocrisy of the "Whig Corporation" of Birmingham. He said that he "thought prosecution came with ill grace from parties who, to serve themselves, had been guilty of greater enormities." He pointed out that his present prosecutors had applauded him for reading newspapers in the streets in 1832 . After this speech there was little hope for his plea for mercy, on the grounds that he had seven children, the oldest of whom was nine. The judge was unimpressed and "felt bound to pass a severe sentence" because of the dangerous situation in which Brown had placed the public. A more discreet Henry Wilkes fared better. When he and a London Chartist were arraigned together, the public prosecutor dropped the charges against them "in consequence of their having abstained from Chartist agitation since the last Assizes."2 The ruling classes had reminded the Chartists of their absolute weakness. Docility would be rewarded and militancy punished.

The realities of power contributed to the triumph of the moderate Chartists over the O'Connorites in Birmingham in the next few years. An artisan who knew that he would be jailed if he carried his politics to what the middle classes considered an extreme had a strong incentive for supporting a less militant political movement. On his release from prison a chastened Edward Brown joined the Christian Chartist group that had challenged the physical force extremists. ${ }^{3}$

Yet the threat of force was of relatively minor importance in creating the moderate working-class political movement that appeared toward the end of 1840 . By far the most important factor was the outlook of the respectable artisan. Despite the crushing disappointment of I 839 , he could not bring himself to jettison all the values and ideals that gave meaning to his life. The political upheavals had not disturbed

1 Ibid., II January, I 8 January 1840.

2 Ibid., 4 April I 840.

3 Ibid., 3 I July I 84 I. 
his position in a well integrated culture or upset his commitment to the value system of the community. He continued to put his faith in rationality, morality, individual self-improvement, and the rightness of the existing social order. He continued to need the approval of his social superiors, however much he might resent their political perfidy. Inevitably, the respectable artisan rejected the physical force approach of the O'Connorites and supported the movement that came to be known as Christian Chartism. The choice of Christian symbolism reflected his preference for a political creed more in harmony with the local ethos than the alien doctrines of O'Connor. Nevertheless, even the Christian Chartists resented the middle-class betrayal of Radicalism and at the outset insisted on avoiding any collaboration with their social superiors.

\section{IV}

A Christian Chartist Church was founded in Birmingham in December of 1840 by Arthur O'Neill. O'Neill had been a theology student at the University of Glasgow, where he became a Chartist in 1839 . In July of 1840 the Glasgow Chartists sent him to Birmingham as a delegate to the celebration being held in honor of the release of Lovett and Collins from prison. O'Neill was familiar with the Christian Chartist movement that had begun in Scotland, and he soon realized that the religious and political convictions of the Birmingham artisans would make them receptive to a similar organization. ${ }^{1}$

The Christian Chartist Church in Birmingham represented an attempt to combine religious forms with an affirmation of faith in the political program of Chartism. Meetings opened with the singing of hymns, often out of a special Chartist hymn book; then O'Neill preached a sermon, based on a Scriptural text; prayers followed.2 O'Neill emphasized the Christian character of his Chartist Church: "The true Christian church could not remain aloof, but must enter into the struggles of the people and guide them. The characteristic of members of a real church was on the first day of the week to worship at their altar, on the next to go out and mingle with the masses, on the third to stand at the bar of judgment, and on the fourth perhaps to be in a dungeon. This was the case in the primitive church, and so it ought to be now." "3 O'Neill also called on his followers to observe the canons of respectability - to be dignified and avoid billingsgate. With characteristic Evangelical zeal for good works, the Christian Chartists

\footnotetext{
1 Ibid., I August I 840, 2 January I841; Birmingham Mail, 9 December 1890.

2 B. J., 9 January I 84 I, I January I 842 ; H. Solly, James Woodford, Carpenter and Chartist (London, I88 I), II, p. 90; 'These Eighty Years (Loncion, 1893), I, p 382.

3 Parliamentary Papers, I843, XIII, p. 137.
} 
were not content to limit their public activity to politics. A sympathetic observer described the earnestness with which they carried out the non-political aspects of their mission: "If a neighbour or a neighbour's child were ill, a 'Christian Chartist' was sure to be ready to run for the doctor or sit up to nurse all the night long. If help were wanted for a burial, half a dozen Christian Chartists would volunteer to carry his coffin. If a fight had to be stopped or a quarrel prevented, there were Christian Chartists ready to do it."1 The Christian Chartists embodied the best features of the prevailing moral code. Their faith in that code was never shaken, although they had grave doubts about the political virtues of their social superiors.

Although they rejected physical force, the Christian Chartists shared the O'Connorites' animosity toward the middle classes. O'Neill emphasized that he intended to organize a purely workingclass movement. In August of r 840 he wrote a letter to "the workingmen of England", in which he argued that they had made a mistake in ever uniting with the middle classes, and suggested that they ought to have paid more attention to Henry Hunt's warnings against such a policy. ${ }^{2}$ William Empson, one of O'Neill's lieutenants, joined him in decrying any union with the middle classes. ${ }^{3}$ For their part, the middle classes had no intention of encouraging such a union; the Christian Chartists were even refused permission to hold a meeting in the Town Hall. They protested against this refusal by interfering with other public meetings. ${ }^{4}$

Despite their rebelliousness and resentment, however, the Christian Chartists carefully avoided any permanent entanglements with O'Connor and the physical force group. On several occasions they intervened successfully to prevent the O'Connorites from taking over the local Chartist movement. They won an important victory in March of I 84I, when they upset George White's plans to mobilize public support for the National Charter Association. The Christian Chartists persuaded a meeting called by White not to back the Association until its rules had been investigated and its legality established. Empson's remarks pointed up the differences between the Christian Chartist and the O'Connorite approach: "He knew there were men who would sanction any rules. If it had not been for such men, they would not have had the Birmingham burnings or the Welsh riots." 5 A few

1 Solly, Woodford, II, p. 90.

2 B. J., is August 1840.

3 Ibid., 23 January $184 \mathrm{I}$.

4 Ibid.

5 Ibid., ${ }_{3}$ March 184 r. 
weeks later the moderates won another victory, when they persuaded a public meeting to elect John Collins, rather than an outsider picked by White, as delegate to the Convention. ${ }^{1}$ Just as in 1832 the National Union of the Working Classes had failed to convert the Birmingham artisans to its alien doctrines, so the O'Connorites, under far more favorable circumstances, failed to secure a firm foothold in the town. The triumph of the Christian Chartists foreshadowed a return to a more familiar pattern of local politics.

But it was only a portent. Despite the clashes between Christian Chartists and O'Connorites, there was a great deal of co-operation between the two groups throughout I84I, based on a common support for the Charter and shared hostility to the middle classes. When the two factions were not quarreling about O'Connor and physical force, their spokesmen sounded very much alike. John Collins, for example, came very close to the O'Connorite position at the time of his election to the Convention. He argued that mere petitioning was not enough, but that something more was necessary: "a great effect must be produced through the Convention". The "anomaly of immense wealth and great poverty" must not be allowed to continue; "they would put a stop to it, let the consequence be what it might." 2 In May of 1841 the Christian Chartists collaborated with White's group in defeating an anti-Corn Law resolution at a public meeting convened by the repealers in the Town Hall. The motion for rejection was introduced by White, seconded by a Christian Chartist, Benjamin Hill, and supported by Collins and O'Neill. ${ }^{3}$ During the general election in July both groups displayed hostility to the Liberals. The Birmingham Journal complained that Empson, O'Neill, Collins, White, and Hill had been "placarding, and speechifying, and deputationizing with all their power, not to help, but to hinder the Liberal cause." The charge was exaggerated, and Collins denied it, but the words accurately described the sentiments, if not the actions, of the Chartists in the summer of $184 \mathrm{r}$. Empson did, in fact, campaign for the Tories, and in August he publicly defended them against the Whigs. ${ }^{5}$ Even a staunch Radical like T. C. Salt was not exempt from the artisans' unremitting hostility toward the middle classes. In September O'Neill and Empson joined White and Brown in an invasion of a meeting of "burgesses" that had been called by Salt to consider financial problems. When Salt told them that "bur-

1. Ibid., 3 April 1841 .

2 Ibid.

3 Ibid., 29 May I 84 I.

4 Ibid., 17 July I 841 .

5 Ibid., 14 August 1841 , 16 March 1842. 
gesses" did not include workingmen, they refused to leave, and he had to hold his meeting elsewhere. ${ }^{1}$ In these and other ways the Christian Chartists dramatized their repudiation of the traditional pattern of politics in Birmingham.

The spirit of protest and revolt among the Christian Chartists was largely confined to the political sphere, however. The ritual of hymns, prayers, sermons, and tea parties bespoke an impulse to respectability and conformity that was incompatible with continued repudiation of middle-class political leadership. Even in $184 \mathrm{r}$ there were signs that the respectable artisans needed only a little encouragement to abandon the posture of revolt that they had maintained since I839. In July, for example, the release of Edward Brown from jail provided the occasion, not for some justifiable recrimination about middle-class justice, but for a tea party that elicited the highest praise from the Birmingham Journal: "The evening was spent in great good humour, and the enjoyment was of the most orderly and rational kind." 2 That sentence incapsulates a great deal of the social and political history of Victorian Birmingham. The artisans were playing the role assigned them by the culture, and their social superiors provided them with the approval that they craved. The same pattern prevailed at another tea party in October of $184 \mathrm{I}$, when the Christian Chartists honored John Collins "before three hundred and fifty well-dressed and most orderly conducted working men, and their wives and daughters." After a prayer by O'Neill, hymns were sung. In accepting a gift of a silver-mounted ink stand, an outside Chartist declared that "no beneficial revolution could be effected in this country which was not based upon the moral and intellectual culture of the people." ${ }^{3}$ The same atmosphere of morality, rationality, and respectability prevailed at the Chartist Church's anniversary celebration in December. Almost a thousand artisans and their wives assembled in the Town Hall, which had finally been made available to them. They drank tea, ate plum cake, sang Chartist hymns, and listened attentively to speeches. From the chair John Collins praised the orderliness and virtue of the working class and deplored the fact that the upper classes acquired their ideas about the character of the common people from idlers, felons, and pickpockets. The crowd acclaimed Joseph Sturge, who expressed his agreement with those who advocated peaceful means of winning an extension of the suffrage. ${ }^{4}$

1 Ibid., 18 September I841.

2 Ibid., 3 I July I 84 I.

3 Ibid, 2 October I 84 I.

4 Ibid., I January 1842. 
A few weeks later Joseph Sturge established the Complete Suffrage Union, which utilized the Christian Chartist impulse to respectability to redirect working-class political activity into the old channels, with the artisans pursuing their objectives under the leadership of their social superiors. The rapidity with which the Christian Chartists threw their support to the C.S.U. indicated clearly that they had adopted only reluctantly the isolated role that the middle-class political withdrawal had forced upon them. They were delighted to return to the old ways that they found so much more congenial than class conflict and controversy. By April of I 842, O'Neill had ceased his attacks on the middle class and was taking a very different line: "And so you see all the prejudice against us has been lived down, and we stand so well in this town that we have only to go to any of the wealthy, benevolent men of Birmingham and tell them we want a little money for this or that, and we get it immediately." 1

As a middle-class organization committed to universal manhood suffrage, the Complete Suffrage Union served as a bridge between the classes that had been divided by the Chartist upheaval. At the critical moment, when even moderate elements among the workingmen had lost confidence in the leadership of the middle classes, Sturge and his colleagues intervened dramatically to show that a few merchants and manufacturers were as dedicated as ever to the cause of parliamentary reform. At the same time the C.S.U. reminded the local bourgeoisie that the Birmingham working class was at heart the very model of political moderation and respectability. Once mutual distrust had been dissipated, relations between the classes became increasingly cordial. As a result of Sturge's creative initiative the forces of cultural cohesion that had been immobilized by the Chartist crisis could operate once again to encourage the politics of class harmony.

1 Solly, Woodford, II, p. 91. 